would certainly receive direct evidence of the validity of the document ${ }^{25}$ exercising the power, since the document obviously could not be admitted to probate. Such a position was suggested in Sewall v. Wilmer ${ }^{26}$ where the donor provided that the trust res be disposed of as the donee "shall direct ... by ... her last will and testament, . . or by a writing purporting to be her last will ... to be by her duly executed in the presence of ... three credible witnesses. ... ${ }^{\text {s27 }}$ Chief Justice Gray, writing for the Massachusetts Supreme Judicial Court, indicated in a dictum that probate of the writing "purporting to be her last will" would not have been required. ${ }^{28}$ And, although the dictum goes no farther, it could be read to imply that a court construing the donor's will, for the purpose of determining whether the donee's will was in compliance with its provisions, would have received evidence to determine whether the "writing purporting to be her last will and testament" was, as required by the donor's will, "executed [by the donee] in the presence of . . . credible witnesses. . . ."29 Such a determination does not differ, under some wills statutes, from the determination labelled "probate."

${ }^{25}$ The document may be a deed, McGee v. Vandeventer, 326 Ill. 425, 158 N.E. 127 (1927); or a simple note in writing, Goodloe v. Woods, 115 Va. 540, 80 S.E. 108 (1882).

26132 Mass. 131 (1882).

${ }^{27} \mathrm{Id}$., at 132.

${ }^{28}$ Id., at 137.

${ }^{29}$ Id., at 132.

\title{
RENDERING UNTO CAESAR: STATE HEALTH REGULATIONS AND THE FREE EXERCISE OF RELIGION
}

When state public health regulations have been challenged as an infringement on the free exercise of religion, in violation of the First and Fourteenth Amendments, they have almost uniformly been held constitutional on the basis of four Supreme Court cases which have interpreted the First Amdndment as an absolute protection of "freedom of belief" but not of "freedom of action." The precedent value of these decisions, however, appears to have been greatly diminished by West Virginia Board of Education v. Barnette, ${ }^{2}$ whose impact has not been sufficiently appreciated by state courts. ${ }^{3} \mathrm{It}$ is the purpose of this note to explore the effect of the change in doctrine, manifested by the Supreme Court in the Barnette case, on state power over public health.

\section{I}

In the first case, Reynolds v. United States, ${ }^{4}$ Reynolds, a Mormon, was convicted of the crime of bigamy in the territory of Utah. His defense was that his

1 Cantwell v. Connecticut, 310 U.S. 296 (1940); Jacobson v. Massachusetts, 197 U.S. 11 (1905); Davis v. Beason, 133 U.S. 333 (1890); Reynolds v. United States, 98 U.S. 145 (1878).

2319 U.S. 624 (1943). This case overruled Minnersville School District v. Gobitis, 310 U.S. $586(1940)$.

${ }^{3}$ See Section III infra.

498 U.S. 145 (1878). 
religion made polygamy obligatory. The Court sustained his conviction on the ground that, marriage being a civil contract as well as a sacred bond, the statute was within the legislative power of Congress. In discussing the protection granted under the First Amendment, the Court made a distinction between beliefs and actions: "Congress was deprived of all legislative power over mere opinions, but was left free to reach actions which were in violation of social duties or subversive of good order. ${ }^{15}$ In the next case, Davis v. Beason, ${ }^{6}$ petitioners, also Mormons, took an oath required for electors in the territory of Idaho that they were not bigamists and did not belong to any organization which taught bigamy. They were convicted of a conspiracy to pervert and obstruct the due administration of the laws of the territory. The language of the Court was similar to that in the Reynolds case, and the same policy considerations were operative. ${ }^{7}$

Jacobson v. Massachusetts ${ }^{8}$ involved a Massachusetts statute which empowered the board of health of a city or town to subject its inhabitants to compulsory vaccination against smallpox if deemed necessary for the public health. Cambridge exercised this power and Jacobson was indicted for refusing to be vaccinated. He contested the validity of the statute on the grounds: (1) that the theory of vaccination was not sound; and (2) that the statute was unreasonable in that it required vaccination for everyone even though some persons, like himself, suffered severe adverse effects therefrom. The Court upheld the statute on the ground that the state's police power includes the power to make reasonable regulations for the protection of public health and safety, and it could not be said that this regulation was unnecessary to protect the public health. Although this case has been cited and relied on by both state courts ${ }^{9}$ and the Supreme Court ${ }^{10}$ for the proposition that a person cannot be exempted from compulsory vaccination for religious reasons, there was no allegation in the Jacobson case that petitioner resisted vaccination from religious motives. For example, Zucht $v$. King ${ }^{11}$ relied on the Jacobson case to uphold a Texas city ordinance which excluded from public and private schools children who did not have a certificate of vaccination; the resistance in the $Z u c h t$ case was prompted by religious motives.

In Cantwell v. Connecticut ${ }^{12}$ Jehovah's Witnesses were selling religious literature and proselytizing for their faith in a Catholic neighborhood. They were

5 Id., at 164 . 6133 U.S. 333 (1890).

7 "It was never intended that the amendment could be invoked as a protection against legislation for the punishment of acts inimical to the peace, good order, and morals of society." Id., at 342 .

8197 U.S. 11 (1905).

${ }^{9}$ Mosier v. Barren County Board of Health, 308 Ky. 829, 215 S.W.2d 967 (1948); Sadlock v. Board of Education of Carlstadt, 137 N.J.L. 85, 58 A.2d 218 (1948).

${ }^{10}$ Prince v. Massachusetts, 321 U.S. 158 (1944).

1260 U.S. 174 (1922).

12310 U.S. 296 (1940). 
convicted of breaching the peace and violating a state statute prohibiting the solicitation of funds for any organization (except from members) unless the secretary of the public welfare council determined that the organization was truly charitable or religious, and issued a license for solicitation. The Court reversed the conviction, holding, first, that no breach of peace was proved and, second, that the statute was invalid as a prior restraint on the exercise of religion. ${ }^{13}$ The opinion restated the ideas expressed in the bigamy cases:

The Constitutional inhibition of legislation on the subject of religion has a double aspect. On the one hand, it forestalls compulsion by law of the acceptance of any creed or the practice of any form of worship.... On the other hand it safeguards the free exercise of the chosen form of religion. Thus the Amendment embraces two concepts,freedom to believe and freedom to act. The first is absolute, but, in the nature of things, the second cannot be. Conduct remains subject to regulation for the protection of society. 14

Under the test then developed, it appears that legislation is unconstitutional only if it violates the "freedom to believe."

Drawing the line between protected and unprotected exercises of religion on the basis of whether freedom to believe or freedom to act is involved may be criticized on several grounds. The language of the Amendment gives no hint of this distinction, ${ }^{15}$ the word "exercise" ordinarily would not be thought restricted to belief. Second, if Congress and the states were "deprived of all legislative power over [only] mere opinions," then it must be assumed that prior to the First Amendment Congress, and before the Fourteenth Amendment the states, could effectively control belief. The usual means of control, censorship or punishment, must, however, necessarily involve only the manifestation of a belief. ${ }^{16}$ Third, it may be suggested that restricting the guarantee of free exercise of religion to the free exercise of religious beliefs defeats the purpose of the guarantee itself. An analogy to the free speech provision is useful here. Guaranteeing an individual the right to speak freely may serve one or more of the following purposes: (1) provide an element indispensable for his personal happiness; (2) save society from disruption and discord consequent to the stifling of individual expression; (3) provide the means whereby people may compare ideas circulating in the "market place" and sift the true ideas from

${ }^{13}$ Although the Cantwell case held a state statute invalid as a violation of the First Amendment, the basis of the decision was that civil authorities have no power to decide what is and what is not a religious organization. The implication is that the power to define involves the power to sanction or prohibit, to establish or disestablish. In spite of the language touching the "free exercise" clause, Cantwell seems really to have dealt with the "establishment of religion" clause.

${ }^{14}$ Cantwell v. Connecticut, 310 U.S. 296, 303 (1940).

15 "Congress shall make no law respecting an establishment of religion; or prohibiting the free exercise thereof." U.S. Const. Amend. I.

${ }^{16}$ See dissenting opinion in State ex rel. Holcomb v. Armstrong, 39 Wash.2d 860, 867, 239 P.2d 545, 549 (1952). 
the false. ${ }^{17}$ Guaranteeing an individual the right freely to practice his religion may also serve one or more of these objectives, with "religious practices" substituted for "ideas" in the third. ${ }^{18}$ Just as these objectives could not be achieved in the free speech area if the guarantee were limited to thoughts, or inchoate speech, ${ }^{19}$ neither may they be secured in the religious area if only beliefs are protected.

As the Davis case indicates, the primary purpose of distinguishing between beliefs and actions was to insure society protection from those religiously motivated activities, which, according to secular law, are criminal. ${ }^{20}$ But it is not necessary to put all religious action outside the First Amendment protection in order to achieve this end. A sacrifice of one individual's life by another to appease a deity ${ }^{21}$ is no more an exercise of religious freedom than is the counselling of murder an exercise of free speech;22 both may properly be made the subject of criminal prosecution. But because the counseling of murder is not protected speech does not mean that any speech advocative of policies contrary to those adopted by the state may be curtailed; similarly the concept that freedom of religious action is not absolute does not obviate the need for determining what religious actions are exempt from legislative interference. The Court's dictum that action could be curtailed only if subversive of the "good order," "morals," or "protection" of society in effect gave the states carte blanche authority over religious activity so long as the legislation bore a reasonable relation to "good order" or "morals."

The need for a more refined definition of constitutionally protected religious activity was impliedly recognized by the Court in both the Davis and Canivell cases. In Davis the Court said: "[petitioner may] exhibit his sentiments in such form of worship as he may think proper, not injurious to the equal rights of others. ...", ${ }^{23}$ and in Cantwell: "The freedom to act must have appropriate definition to preserve the enforcement of that protection [of society]. In every case the power to regulate must be so exercised as not, in attaining a permissible

${ }^{17}$ See Richardson, Freedom of Expression and the Function of Courts, 65 Harv. L. Rev. $1,3-4$ (1951).

${ }^{18} \mathrm{Of}$ course one of the main purposes of religion is not mentioned here: salvation. The omission was intended, because a strictly secular government cannot have a policy about salvation.

${ }^{19}$ See Mr. Justice Douglas' dissent in Dennis v. United States, 341 U.S. 494, 582-83 (1951).

20 "However free the exercise of religion may be, it must be subordinate to the criminal laws of the country, passed with reference to actions regarded by general consent as properly the subjects of punitive legislation." Davis v. Beason, 133 U.S. 333, 342-43 (1890).

21 "Suppose one believed that human sacrifices were a necessary part of religious worship, would it be seriously contended that the civil government under which he lived could not interfere to prevent a sacrifice?" Reynolds v. United States, 98 U.S. 145, 166 (1878). This was part of the Court's argument why religiously motivated action should not be outside the cognizance of the civil government.

22 Frohwerk v. United States, 249 U.S. 204, 206 (1919).

${ }^{23}$ Davis v. Beason, 133 U.S. 333, 342 (1890). 
end, unduly to infringe the protected freedom."24 Thus, even if the state power were rationally exercised in a proper area it may infringe the "appropriate definition" of the protected freedom. The test of "undue" infringement of this freedom remained to be pronounced by the Court in West Virginia Board of Education ข. Barnette. ${ }^{25}$

In Barnette, the Court struck down a state statute which required children to salute the flag in a school ceremony. Children who refused to comply were expelled, considered delinquent, and their parents were subject to criminal prosecution. The Court admitted that the statute, except for the restrictions imposed by the First Amendment as incorporated in the Fourteenth Amendment, was valid, i.e., it was a rational means of achieving a legitimate state objective, but held that the protected freedoms cannot be infringed "on such slender grounds [as were presented in this case]. They are susceptible of restriction only to prevent grave and immediate danger to interests which the state may lawfully protect."26

In spite of the holding that some religious activities are immunized from state legislation rationally designed to achieve legitimate state objectives, the Court also relied on the traditional tests of judging state legislation. The words "slender grounds" in the passage quoted show that the Court did not think it too important to uphold state power in the "patriotism" area. There are, in addition, long passages in the opinion in which the Court suggests that, if patriotism is the desired objective, compelling persons to salute the flag against their religious beliefs is a dubious means of achieving that objective. Furthermore, the statute in question comes very close to being an attempt to channel belief; $;^{27}$ the Jehovah Witness children offered to pronounce, without raised hand, certain words of pledge similar to those required by the statute. This action did not sufficiently conform to the statutory requirements. Thus an inflexible application of the Court's definition of protected religious activity-action which does not present a grave and immediate danger to interests which society may lawfully protect-ignores the special circumstances which it is suggested weighed heavily on the Court in Barnette.

Indeed a strict application of the grave and immediate danger test was rejected by the Court the following year in Prince v. Massachuselts. ${ }^{28}$ In that case members of the Jehovah Witness sect were convicted of violating a state statute which prohibited minors from selling newspapers in public places and held parents permitting such sale criminally liable. The petitioners asserted that the

24 Cantwell v. Connecticut, 310 U.S. 296, 304 (1940).

25319 U.S. 624 (1943).

${ }^{26}$ Id., at 639. ${ }^{27}$ Id., at $631,633$.

28321 U.S. 158 (1944). Mr. Justice Murphy dissented from the majority opinion on the ground that the state did not meet the burden of proving that invalidation of the statute would result in a "grave and immediate danger to the state or to the health, morals or welfare of the child." Id., at 174. 
statute could not violate the children's free exercise of religion without a showing that it was necessary to protect society from a grave and immediate danger. The Court rejected this contention on the ground that the state can regulate children in ways it cannot regulate adults; the child's protected free exercise of religion is more circumscribed than that of the adult. Although the Court did not demand that the state show grave and immediate danger either to its own interests or that of the child, the rationale given nevertheless presupposed that there is an area of activity protected by the First Amendment against legitimate state legislative power. The area was defined only in that its limits were drawn differently for adults than for children. ${ }^{29}$ Justice Jackson's opinion in Prince sought to establish a more specific basis for defining the protected area: "I think the limits being to opera te whenever activities begin to affect'or collide with liberties of others or of the public." 30 This in effect is a broader area than that suggested by his opinion for the majority in Barnette, in so far as Barnette would substitute "interests" for "Jiberties" but narrower in that Barnelte substitutes "[pose a] grave and immediate danger" for "affect."

Indeed, very little state legislation would be valid if the justification had to be protection of affirmative personal liberties of the public rather than a regulation of conduct for broad state purposes. Jackson's opinion does add, however, an important concept earlier found in the Davis case: the interests that the state seeks to protect must be those of others, or of the public; put in terms of Barnette there must be a grave and immediate danger to others or to the public. Presumably, in Jackson's usage the "public" does not modify "others" so as to include the practitioners, but refers to interests which an individual would not have standing to assert.

II

In spite of the peculiar facts and circumstances under which the Barnette test arose, and its subsequent modification by Prince, it should nevertheless be clear that Barnette marked a turning point in the interpretation of the First Amendment. The need for some refinement of the First Amendment, such as that made in Barnette, is clearly indicated by a comparison between Congressional and state power. Since Congress may legislate only within its enumerated powers, it is possible to interpret the First Amendment as defining, in part, the powers the Constitution assigns Congress. According to this interpretation, congressional legislation which prohibited the free exercise of religion would have been invalid before, as well as after, the passage of the Amendment because Congress lacks a constitutional grant of power to enact the legislation. ${ }^{31}$

${ }^{29}$ Although children were involved in Barnette, there was no allegation in that case, as in Prince, that the regulation was for the dissenting childrens' own welfare.

${ }^{30}$ Prince v. Massachusetts, 321 U.S. 158, 177 (1944).

31 "I go further, and affirm that bills of rights, in the sense and to the extent in which they are contended for, are not only unnecessary in the proposed Constitution, but would even be dangerous. They would contain various exceptions to powers not granted; and, on this very account, would afford a colorable pretext to claim more than were granted. For why declare 
This interpretation of the First Amendment is not, however, applicable to the powers of states. Save for express constitutional limitations on the powers of states such as the Impairment of Obligations and Full Faith and Credit Clauses, and the general limitation imposed by the Supremacy Clause, the states were not hampered from passing laws directly prohibiting the free exercise of religion. ${ }^{32}$ Unless the passage of the Fourteenth Amendment and the subsequent constitutional doctrine of the incorporation of the First Amendment into the Fourteenth Amendment ${ }^{33}$ deprived the states of their former power to legislate a prohibition on the free exercise of religion, the broad general welfare and mortality powers of the states would, even after the passage of the Fourteenth Amendment, support any state legislation, no matter how much it infringed the free exercise of religion, so long as there was a rational basis for the legislation.

Suppose, for example, a state were to pass a law requiring compulsory church attendance by all persons under twenty-five because statistics showed that young people who regularly attend church are rarely found in the criminal and juvenile courts. Suppose further that while the law was in existence and until it was tested in the courts the crime rate among persons affected dropped markedly. Whereas Congress could pass this kind of legislation only in pursuance of its enumerated powers even if the First Amendment were considered to have effected no deprivation of congressional power, this legislation if passed by a state would be constitutional unless the First Amendment as incorporated in the Fourteenth Amendment is considered a deprivation of state power. ${ }^{34}$

It is, of course, also possible to interpret the First Amendment guarantee of the free exercise of religion as a limitation on Congress' power. The prohibition against congressional abridgment of free speech, contained in the same Amendment, has in fact been interpreted as a restriction on Congress' enumerated powers; thus speech may be abridged by Congress only if it incites a "clear and present danger" 35 even though speech which does not fall in that category may interfere with the exercise of an enumerated power. ${ }^{36}$ Since the guarantee of

that things shall not be done which there is no power to do? Why, for instance, should it be said that the liberty of the press shall not be restrained, when no power is given by which restrictions may be imposed?" The Federalist No. 84 .

${ }^{32}$ See Pennoyer v. Neff, 95 U.S. 714 (187)). But for the view that a concept like "due process of law" was operative on state legislation before the Fourteenth Amendment see Howe, The Meaning of "Due Process of Law" Prior to the Adoption of the Fourteenth Amendment, 18 Cal. L. Rev. 583 (1930).

${ }^{33}$ West Virginia Board of Education v. Barnette, 319 U.S. 624, 639 (1943); Cantwell v. Connecticut, 310 U.S. 296, 303 (1940); Schneider v. New Jersey, 308 U.S. 147, 160 (1939); Gitlow v. New York, 268 U.S. 652, 666 (1925).

${ }^{34}$ Although the legislation might raise problems under the "establishment of religion" clause, it may be contended that the churches are only incidental beneficiaries under this legislation. Cf. note 58 infra.

${ }^{35}$ Schenck v. United States, 249 U.S. 47, 52 (1919).

${ }^{36} \mathrm{Cf}$. Ex parte Milligan, 4 Wall. (U.S.) 2 (1866). See Chafee, Free Speech in the United States 30-31 (1941). 
freedom of speech contained in the First Amendment has been construed as a limitation on Congress' power, the Fourteenth Amendment should a fortiori have effected a similar restriction on states because, as stated above, state powers are general, not enumerated.

\section{III}

State courts have, however, continued to base their decisions on the constitutionality of state action in the health field according to whether the "freedom to believe" or "the freedom to act" is being restricted, provided always, of course, that the legislation is a rational means of achieving a legitimate state objective. When these courts conform to the change in doctrine established by Barnette, they will face problems which will differ depending on the particular health regulation involved.

Non-communicable diseases. - No cases have arisen in which the state sought to compel adult persons to submit over religious objections to examination or treatment for non-communicable diseases. ${ }^{37} \mathrm{~A}$ parents' right to prevent such treatment for his child where no other persons were in danger of being infected has, however, been before the courts.

It was held in New York that a parent is criminally liable for refusing on religious grounds to provide medical attention for his child. ${ }^{38}$ Although the defense was based on the religious freedom guaranteed by the New York, not federal, constitution, the United States Supreme Court has cited the holding as if a First Amendment privilege were concerned. ${ }^{39}$ Application was made to an Illinois Court to appoint a guardian to authorize a blood transfusion for an eight-day old infant who was expected to die without it. The parents, Jehovah Witnesses, had refused to authorize the transfusion because their sect interprets the biblical injunction against eating blood as prohibiting blood transfusions; if the injunction were violated it was contended that the eight-day old infant would suffer eternal damnation. The trial court granted the application and the Supreme Court of Illinois affirmed. ${ }^{40} \mathrm{~A}$ Missouri court reached the same result

${ }^{37} \mathrm{But}$ in the case of Martin v. Industrial Accident Commission, 147 Cal.App.2d 137, 304 P.2d 828 (1956), the deceased's wife was refused workmen's compensation because the Workmen's Compensation Commission determined that death was proximately caused by the "employee's unreasonable refusal to accept medical treatment" after the accident. The widow claimed that this constituted a finding that the deceased's religion was unreasonable and as such violated First Amendment rights. The court bypassed this argument by holding that the legislature could fix the condition of the employer's liability upon the employee's acceptance of medical care.

${ }^{38}$ People v. Pierson, 176 N.Y. 201, 68 N.E. 243 (1903). The disease in this case was whooping cough, which is communicable, but the case is placed here because the child was isolated and no question was raised of anyone else being in danger of contracting whooping cough; the sole rationale for treatment was for the diseased child's welfare.

${ }^{39}$ Prince v. Massachusetts, 321 U.S. 158, 167 (1944).

${ }^{40}$ People ex rel. Wallace v. Labrenz, 411 Ill. 618, 104 N.E.2d 769 (1952), cert. denied 344 U.S. 824 (1952). The case was moot when it reached the Illinois Supreme Court, since the infant had been given the transfusion and had recovered, but the Illinois Supreme Court agreed 
upon substantially similar facts; it upheld the right of the trial court to declare the child "neglected" under an appropriate statute, and thus a ward of the court. ${ }^{41}$

Under the Barnette test religious practice may be limited only when it presents a grave and immediate danger to others or the public; the decisions adhere to the rule providing that the infants are considered "others" than their parents. The Illinois court relied heavily on the Prince case, but it should be noted that in the Prince case the child was claiming freedom of the exercise of his own religion. Since an eight-day old infant is capable of exercising only the most primitive human functions, it is the parents' right of exercising his religion as to the child that is here being restricted. Because no infant can exercise religion, he must fall within the category of "others."

The troublesome aspect of these cases is that the parents claim the state action will result in a grave and immediate danger to the child: eternal damnation. ${ }^{42}$ But if courts were to condition their decisions according to the doctrines of a religious sect, a serious First Amendment problem would arise, for litigants in identical situations would be treated differently. ${ }^{43}$

The New York case mentioned above which upheld a criminal conviction for neglecting to provide a child medical care may be cited as a fortiori authority for court authorization of the medical care. Generally, the only areas in which an individual may thwart legislative objectives by choosing punishment rather than compliance are those where obedience can be secured only by the use of brute force-contempt of court-or could not even be achieved thereby-military conscription. It may thus be argued that an individual does not have the privilege of subjecting himself to criminal sanctions as an alternative to compliance with legislation. Although granting an individual this choice in the religious area may seem in derogation of the First Amendment, at least the parent may thereby protect the spiritual interests of his child at the expense of his own temporal ones. That is, imprisoning a parent for refusal to allow his infant a transfusion is different from authorizing the transfusion over the parents' ob-

to hear the case despite its mootness because of the importance of settling this question of public interest. For this kind of case to be considered by the United States Supreme Court the malady would have to be a lingering one.

41 Morrison v. State, 252 S.W.2d 97 (Mo.App., 1952). In both the Illinois and Missouri cases, the infant was returned to its parents after the transfusion.

42 "Immediate" is not used here in the sense of time, for the transfusion presumably postpones the time when the child will pass into the next world, but is used in the sense of "highly probable" or "certain." See text at note 51 infra.

${ }^{13}$ The court in the Missouri case indicated that the passages relied on by the Jehovahs Witnesses were subject to other interpretations, but then disclaimed any attempt to base the decision in that case on an interpretation of the Bible. It is questionable, however, whether if the court considered reasonable the parents' claim that the blood transfusion would effect the eternal damnation of the child, it would have had so righteous an attitude about its authorization of the transfusion. 
jection, for in the first the court performs a civil function-consigning the parent to jail-whereas in the second it performs a non-civil function-it may send the infant to hell. The price of this distinction is the life of the infant. Whereas the foregoing distinction may serve as a justification for permitting one individual to choose between compliance and punishment in this area, no such justification appears where one individual is choosing for another, even though the relationship is as close as parent and child.

Communicable diseases. - Where persons who may be suffering from communicable diseases are involved, a different problem arises, because their religiously motivated reluctance to submit to examination or treatment may subject others to grave and immediate danger. State regulations compelling smallpox vaccination for schoolchildren have, when challenged, been upheld on the basis of Jacobson. ${ }^{44}$ The $Z u c h t$ case is, of course, direct authority for sustaining the constitutionality of vaccination for schoolchildren against a claim of First Amendment protection. Since $Z u c h t$ relied completely upon Jacobson, and no claim of infringement of religious liberty was made in Jacobson, the authority for the constitutionality of these regulations is weakened. Applying the Barnette test to compulsory smallpox vaccination for adults weakens the Jacobson authority further, because the nature of the vaccination serum is such that it protects inoculated persons from contracting smallpox from diseased persons; thus inoculation of religious dissenters does not protect others from a grave and immediate danger. ${ }^{45}$ The only justification for including the persons who put themselves in danger in the category of those who must be protected from the danger would be the public interest in preventing the risk of death-burial expenses and possible dependent support. ${ }^{46}$ These seem indeed to be "slender grounds" for circumscribing the free exercise of religion. The regulation of children in this area does, however, seem to accord with the narrower area of protected religious freedom accorded children by the Prince case which made clear that the state may protect children from harmful effects of the practice of their own religion whereas it may not always do so to adults.

${ }^{44}$ See authorities cited note 9 supra.

45 It may, of course, be argued that there would always be a certain number of personsvagrants, travellers, etc.- whom the state could not reach in its vaccination program; the religious dissenters would therefore be endangering these persons. But these persons gain a high degree of immunization as a result of the vaccination program, and are therefore not so endangered as might at first be supposed. "The nature of herd immunity will become clear at this point, for the higher the proportion of immunes in a population the smaller the probability of effective contact between case and susceptible; i.e., many of the contacts will be with immunes, and the population exhibits a group resistance to epidemic diseases which may be of such a high order that an epidemic is no longer possible and the disease smolders in an endemic form. ... A susceptible member of such an immune population, then, enjoys an immunity that is not of his own making but arises as a result of his membership in the group." Burrows, Textbook of Microbiology 217 (16th ed., 1954).

${ }^{46}$ It may also be contended that the public has an interest in keeping persons alive, even against their own will, in order that they produce material benefits for society. So basic a policy question is beyond the scope of this note. 
When state police power to protect the public health is exercised to prevent contagion of a disease for which no protective device like serum is available, the Barnette test indicates that the constitutional claim would fail. Thus a Florida decision which upheld the constitutionality of a statute confining petitioner, a tuberculosis victim and religious non-believer in medical care, to a sanatorium is proper. ${ }^{47}$ If, however, the state sought to administer medical treatment under an applicable statute to the tuberculosis victim, the interest protected-saving the expense of confinement-seems again insubstantial; under the Barnette test confinement removes the grave and immediate danger to others.

The right of a state to force religious objectors to submit to a medical examination for communicable disease was considered in State ex rel. Holcomb v. Armsirong. ${ }^{48}$ In that case, the majority opinion found that a regulation of the state university requiring entering students to submit to a chest X-ray for the detection of tuberculosis was necessary to protect university students from a clear and present danger ${ }^{49}$ to their health..$^{50}$ The dissent stated that there was no evidence presented of how many students of Christian Science persuasion, like the plaintiff, applied for admittance, but even if there were two hundred such students, which was said to be a high estimate, on the basis of other statistical evidence of the incidence of tuberculosis, the probabilities were that one non-X-rayed Christian Science student in seven and one-third years would be admitted with the disease. This, the dissent stated, was no present or immediate danger.

This interpretation of the requisite of "presentness" or "immediacy" has not, with good reason, been adopted in the free speech area. The clear and present danger test should be interpreted, at least partially, to exact a causal relationship of the exercise of religion to the danger-talked about by the Supreme Court in terms of "natural tendency" and "probable effect." The tuberculosis $\mathrm{X}$-ray case satisfies to a high degree the test of causation between the exercise and the danger. As Judge Hand's opinion in United States v. Dennis ${ }^{52}$ points out,

${ }^{47}$ Moore v. Draper, 57 So.2d 648 (Fla., 1952).

1839 Wash.2d 860, 239 P.2d 545 (1952).

49 The similarity of the words "grave and immediate danger" to the "clear and present danger" criterion used in the free speech area has resulted in confusion of the two by state courts. The two standards, though, are not very different. The probability criterion inherent in "clear" is also relevant to the term "present" or "immediate." Likewise, it is expected that the "danger" in the free speech area must be substantial, if not grave. For an excellent discussion of the meaning of the "clear and present danger" criterion in this connection see Richardson, op. cit. supra. note 17.

${ }^{50}$ Although it may be said that the state was here withholding a benefit from, rather than enforcing an obligation upon, a person, it is submitted that this distinction is not important in this context. First, the distinction was not relied on by the state court, and second, the Barnette test makes no distinction between regulations governing voluntary or involuntary actions.

${ }^{21}$ Debs v. United States, 249 U.S. 211, 215 (1919); Schaefer v. United States, 251 U.S. 466, 479 (1920); Pierce v. United States, 252 U.S. 239, 244 (1920).

b2 183 F.2d 201 (C.A.2d, 1950). 
the requirement of proximity is imposed to satisfy the requirement of causation or probability::33

Granted the same probability, it would be wholly irrational to condone future evils which we should prevent if they were immediate; that could be reconciled only by an indifference to those who come after us. It is only because a substantial period between the utterance and its realization may check its importance, that its immediacy is important. ${ }^{54}$

Since the probability of harm in the X-ray case does not decrease with the lapse of time, and since there is considerably less probability that medical science predictions, as opposed to those of social science, of the dangerous consequences of the exercise will prove erroneous, there is no justification for construing the requirement of immediacy literally. ${ }^{55}$ It may be noted, however, that basing the immediacy requirement upon the possible lack of knowledge of effects of religious activity sufficient to justify the infringement of constitutional rights makes sense in the flag salute case, where medical science is not concerned. ${ }^{56}$

Practices increasing risk of death.-Certain religious ceremonies which increase the risk of death have been proscribed by state statutes which make it a criminal offense to exhibit, handle, or use any poisonous reptile so as to endanger the life or health of any person. ${ }^{57}$ These statutes may have been specifically designed to prohibit the practice of the Congregational Holiness Church of using rattlesnakes as a test of faith in a ceremony of baptism; the sect's theory is that true believers will not be harmed. Here as in the compulsory adult vaccination and compulsory treatment of tuberculosis in a sanatorium areas, the only persons being protected from the danger are those who are willingly exposed thereto; again the only interest of the general public is expense..$^{58}$ The public interest in being protected from danger could be adequately served by drafting the statute to make criminal the use of reptiles only where persons not voluntarily subject to the danger were involved. ${ }^{59}$

${ }^{53}$ See Richardson, op. cit. supra note 17.

54 United States v. Dennis, 183 F.2d 201, 212 (C.A.2d, 1950).

${ }^{65}$ The remoteness criterion in the free speech area is also imposed because it is assumed that the longer in time the effect of the speech is removed from its utterance, the more opportunity will there be to expose its falseness. See Richardson, op. cit. Supra note 17. Again this rationale has less application in the medical science area.

${ }^{58}$ This may be another reason for restricting the holding of that case to its facts.

${ }^{57}$ E.g., Alabama: Hill v. State, 38 Ala.App. 404, 88 So.2d 880 (1956); North Carolina: State v. Massay, 229 N.C. 734, 51 S.E.2d 179 (1949), appeal dismissed sub nom. Bunn v. North Carolina, 336 U.S. 942 (1949); Tennessee: Harden v. State, 188 Tenn. 17, 216 S.W.2d 708 (1949).

${ }^{38}$ In Harden v. State, however, the court applied the Barnette grave and immediate danger test and said that reasonable minds agree that the handling of poisonous snakes is a grave and immediate danger to life and health; apparently the question of whose life and health was endangered did not occur to the court. This case illustrates the necessity for defining the object of the danger in terms other than those with which the statute was designed to cope; thus the test of grave and immediate danger to others or the public is the only one in which the legislation is not automatically upheld if it bears a reasonable relation to its purpose.

"It may be contended that drafting the legislation in this manner raises a question under the Establishment of Religion Clause. Indeed, the Barnette formulation itself raises this problem 
Preventive measures against non-communicable diseases.-Certain state health regulations are designed to prevent, rather than detect or cure, non-communicable diseases; these measures ne'cessarily affect large numbers indiscriminately. For example, city regulations have provided for fluoridation of the water supply to prevent dental caries in children. ${ }^{60}$ This legislation may be upheld against a child's allegation of First Amendment infringement ${ }^{61}$ solely under the Prince doctrine: children may be protected from the harmful effects of the practice of their (or their parents') religion. Since, however, this water is made available to adult persons as well as children, the application of Barnette may be in order, and it may be questioned whether caries are properly classified as a "grave" danger, ${ }^{62}$ except, of course, in relation to teeth.

Even if it were decided that dental caries are not a "grave" danger, there are several arguments why this criterion is not applicable to fluoridation. Unlike the vaccination, sanitorium-treatment, and blood transfusion situations, this is not an instance where to do or refrain from doing something believed prohibited or required by religion is involved. The individual has the alternative, albeit burdensome, of procuring unfluoridated water ${ }^{63}$ Secondly, the legislature has determined that this is the best means of securing to the young the benefit of a substantial decrease in dental caries; if the fluoridation regulation were held unconstitutional, those who did not share the objector's religion would be put to expense and inconvenience, if not pain.

The Barnette case, which set forth the grave and immediate danger criterion, differed in precisely these two respects: escaping the effect's of the regulation

because it puts more of a burden on a state to justify action when opposed by religiously motivated violators that when opposed by non-religiously motivated violators. This problem deserves more extended treatment than can be given here; but it may be suggested that in the health area the priority given to religious groups does not raise the establishment problem in an acute form, because the "advantage" given to religious groups here is the opportunity to increase the probability of their own deaths.

${ }^{60}$ E.g., Kraus v. City of Cleveland, 163 Ohio St. 559, 127 N.E.2d 609 (1955); Dowell v. City of Tulsa, 273 P.2d 859 (Okla., 1954), cert. denied 348 U.S. 912 (1955); Baer v. City of Bend, 206 Ore. 221, 292 P.2d 134 (1956); cf. Constitutional Law-Religious Liberty-Fluoridation of Municipal Water Supply, 3 St. Louis U. L. J. 284 (1955).

${ }^{81}$ The Oklahoma court sought to dispose altogether of the claim of First Amendment infringement by saying that fluoridation is not medication. The court was obviously interpreting the plaintiff's religion. Good faith on the part of the religious objector should be sufficient to raise the First Amendment problem.

62 There was a fleeting reference to the clear and present danger test in the Oregon case. Even though some showing of the substantiality of the danger is probably required under this test, note 48 supra, it may impose a less serious danger than that implied by the term "grave." To some extent, then, the Oregon court was applying the incorrect standard in the religious liberty area.

${ }^{63} \mathrm{It}$ is true that in the $\mathrm{X}$-ray case the individual had the alternative of attending another school, although it might have been inconvenient and more expensive. But the $\mathrm{X}$-ray examination could be made a requirement for primary and secondary schools, private or public; no alternative would then be present, and the Barnette test would have to be applied to the $\mathrm{X}$-ray situation. 
subjected one to criminal liability rather than expense and inconvenience, whereas the Court's invalidation of the legislation would not preclude the state from drafting legislation which would enable those who desired the benefits of flag saluting from securing the'm.

It seems, then, that the state burden of proving grave and immediate danger might be modified where the religious objector can escape the effects of the legislation although with expense and inconvenience. In that situation, the state need show only that, there being no other reasonable alternative to achieve the legitimate objectives of the legislation, its invalidation would cause substantial expense and inconvenience to the non-objecting public.

In summary, if state public health legislation continues to be upheld under a broad state power to restrict religious "freedom of action," the protection afforded the free exercise of religion against state interference may be largely vitiated. The rèstriction on state power suggested by the Barnette case must be recognized, for only then can religious freedom be given high priority without endangering the community health level. ${ }^{64}$.Thus adults whose religiously motivated actions endanger their own lives, in the judgment of the community, as in the vaccination, rattlesnake', and sanitorium-treatment cases, should be protected by the First Amendment, but only if others are not imperiled. The "immediacy" requirement should be related to causation and possible fallibility of prediction, rather than merely to "time." Finally, where state legislation protects the public from expense, inconvenience and pain, if not "grave" danger, it should not be invalidated if the religious objectors can escape its effects although with inconvenience and expense. It may be contended that in view of all these qualifications, a new formula could be better devised for the health-First Amendment problem. Until such a test is formulated, the Barnette test must be applied with due regard to the different health problems with which state regulations seek to cope.

${ }^{64}$ It has already been suggested that the non-application or mis-application of Barnette has resulted in the inf ringement of religious freedom; but it should also be apparent that a too literal interpretation of Barnette, as was made in the dissent in State ex rel. Holcomb v. Armstrong, 39 Wash. $2 \mathrm{~d} 860,867,239$ P.2d 545, 549 (1952), may well result in endangering the community health level. 